\title{
Role of probiotics to combat viral infections with emphasis on COVID-19
}

\author{
Aravind Sundararaman ${ }^{1} \cdot$ Mousumi Ray $^{1} \cdot$ P. V. Ravindra ${ }^{2} \cdot$ Prakash M. Halami $^{1}$ (i) \\ Received: 29 May 2020 / Revised: 31 July 2020 / Accepted: 11 August 2020 / Published online: 19 August 2020 \\ (C) Springer-Verlag GmbH Germany, part of Springer Nature 2020
}

\begin{abstract}
Interspecies transmissions of viruses between animals and humans may result in unpredictable pathogenic potential and new transmissible diseases. This mechanism has recently been exemplified by the discovery of new pathogenic viruses, such as the novel severe acute respiratory syndrome corona virus-2 (SARS-CoV-2) pandemic, Middle-East respiratory syndromecoronavirus epidemic in Saudi Arabia, and the deadly outbreak of Ebola in West Africa. The. SARS-CoV-2 causes coronavirus disease-19 (COVID-19), which is having a massive global impact in terms of economic disruption, and, above all, human health. The disease is characterized by dry cough, fever, fatigue, myalgia, and dyspnea. Other symptoms include headache, sore throat, rhinorrhea, and gastrointestinal disorders. Pneumonia appears to be the most common and severe manifestation of the infection. Currently, there is no vaccine or specific drug for COVID-19. Further, the development of new antiviral requires a considerable length of time and effort for drug design and validation. Therefore, repurposing the use of natural compounds can provide alternatives and can support therapy against COVID-19. In this review, we comprehensively discuss the prophylactic and supportive therapeutic role of probiotics for the management of COVID-19. In addition, the unique role of probiotics to modulate the gut microbe and assert gut homeostasis and production of interferon as an antiviral mechanism is described. Further, the regulatory role of probiotics on gut-lung axis and mucosal immune system for the potential antiviral mechanisms is reviewed and discussed.
\end{abstract}

Key points

- Gut microbiota role in antiviral diseases

- Factors influencing the antiviral mechanism

- Probiotics and Covid-19

Keywords Probiotics $\cdot$ SARS-CoV-2 $\cdot$ COVID- $19 \cdot$ Gut-lung axis $\cdot$ Zoonosis

\section{Introduction}

Over the past 4 months, the coronavirus disease-19 (COVID19) has had a massive global impact in terms of economic disruption, the strain on local and global public health resources, and, above all, human health. At the time of writing this review, there were $21,600,000$ positive cases and

Prakash M. Halami

prakashalami@cftri.res.in

1 Department of Microbiology and Fermentation Technology, CSIR-Central Food Technological Research Institute, Mysuru 570020, India

2 Department of Biochemistry, CSIR-Central Food Technological Research Institute, Mysuru 570020, India
$7,74,000$ deaths worldwide. In India, there were 2,600,000 positive cases and 50,921 reported deaths. COVID-19 is caused by highly pathogenic, novel zoonotic severe acute respiratory syndrome-corona virus-2 (SARS-CoV-2) that belongs to the family of SARS-CoVs, which also includes Middle-East respiratory syndrome coronavirus (MERS$\mathrm{CoV}$ ) and SARS-CoV-1. These viruses are enveloped, positive sense single-strand RNA viruses belonging to the large family of Coronaviridae and subfamily Caronavirinae, which infect birds and mammals. The genome size of these viruses ranges from 26 to $32 \mathrm{~kb}$ (Anon 2020a). SARS-CoV-2 binds to angiotensin-converting enzyme 2 (ACE2) receptors on cells via its spike (S) glycoprotein. The $\mathrm{S}$ protein has two domains $\mathrm{S} 1$ and S2. S1 binds to the peptidase domain of ACE2, therefore, termed as the receptor-binding domain (RBD), while S2 catalyses the membrane fusion, thereby releasing the genetic 
material into cells (Hoffmann et al. 2020). Inside the cell, the RNA provides the template for structural proteins such as replicase (R1a/ab), envelope (E), spike (S), membrane (M), nucleoprotein $(\mathrm{N})$, and several non-structural proteins (NS116), uncharacterized protein 14 , protein $9 \mathrm{~b}$ (Anon 2020b). Of them, non-structural proteins are predicted to participate in the host-protein interactions and modulate host-cell signaling pathways. The incubation period presumed to vary between 2 and 14 days. The current understanding of the mode of transmission is incomplete. However, based on the recent outbreaks in various parts of the world, the common mode of transmission includes droplet transmission when an infected person coughs or sneezes and surface contact of droplets that contain virus followed by touching nose, eyes, and mouth. Evidence also points towards vertical transmission to newborns, also by fecal transmission. The typical clinical symptoms of SARS-CoV-2 infection include dry cough (67\%), fever $(88 \%)$, fatigue $(38 \%)$, myalgia $(14.9 \%)$, and dyspnea $(18.7 \%)$. Other symptoms include headache, sore throat, rhinorrhoea, and gastrointestinal symptoms. Pneumonia appears to be the most common and severe manifestation of the infection (Guan et al. 2020). Currently, there is no vaccine or specific drug for COVID-19. Further, the development of new antiviral presents several challenges and requires a considerable length of time and effort for drug design and validation. Therefore, exploring the repurposing, the use of natural compounds can provide alternatives and can support therapy against COVID-19. Currently, no research supports the use of any supplement as adjuvant therapy for the management of COVID-19 subjects. In addition to the SARS-CoV2, avian influenza, ebola, dengue, and Zika viral infections remain poorly controlled around the world (Liu et al. 2016).

The live microbes, which possess health benefits on the host when administered in appropriately adequate amount, are referred to as probiotics and it includes a number of genera of bacteria and yeasts. Probiotics include Lactobacillus, Bifidobacterium, Leuconostoc, Pediococcus, and Enterococcus. The normal gastrointestinal microflora of the humans is populated with microflora that belongs to the genus Lactobacillus and Bifidobacterium. They are safe and widely used in yogurts and other dairy products (López-Moreno and Aguilera 2020). Probiotics play a role in balancing the host defensive immune response, thereby stimulating mucosal barrier function and modulating the immune system (El Hage et al. 2017). Interestingly, intestinal bacteria have been shown to exert the beneficial effects through modulation of vitamin D axis. Through vitamin $\mathrm{D}$ axis, probiotics can protect mucosal barrier integrity and suppress gut mucosal inflammation ( $\mathrm{Li}$ et al. 2015). Further, via vitamin D axis, probiotics can regulate both innate and adaptive immune systems. Its effects include decreasing Th1/Th17 T cells and pro-inflammatory cytokines, such as IL-1, IL-6, IL-8, IFN $\gamma$, and TNF $\alpha$, in favor of Th2 response, increasing Treg, downregulating $\mathrm{T}$ cell-driven
IgG production, inhibiting DC differentiation, and helping maintain self-tolerance, while enhancing protective innate immune responses (Del pinto et al. 2017). The interactions of gut-lung axis influence probiotics role in respiratory diseases, thereby the immune dialogue remains a two-way process. The lung microbiota protects against respiratory infections, primarily by production of granulocyte-macrophage via IL-17 and Nod2 stimulation. In response to lung infections, gut microbiota plays a crucial role. In vivo studies in germ-free mice showed increased morbidity during acute lung infection (Brown et al. 2017). Similarly, modulation in the severity of Mycobacterium tuberculosis infections in lung is correlated with gut microbiota (Namasivayam et al. 2018). Trace elements such as zinc play an essential role in normal growth and development of the host. Zinc has significant effects on intestinal bacterial populations and the immune system by boosting the Th1 immune pathway. The primary mechanism of zinc homeostasis in the body is the gastrointestinal absorption of ingested zinc balanced by the secretion of endogenous zinc into the gut and excretion in the feces (Cummings and Kovacic 2009). The perturbations in zinc homeostasis in human are a critical factor to influence antiviral immunity. The deficiency of zinc leads to the risk of acquiring viral infections as there is an imbalance of the Th1 and Th2 immunity functions, leading to a defect in the Th1 pathway (Gielda and DiRita 2012). Leonardi et al. (2013) showed LAB enriched with zinc could be a valuable source of this element in food, because zinc metalloproteins or bioplexes are the best form for absorption by humans.

The mechanism of how probiotics work on the host organism and immune system is complicated and still not fully elucidated. However, the remedies and effectiveness of vaccines for viral diseases are limited by the high mutation rates of viruses, especially RNA viruses. In this review, we discuss the efficiency of probiotics and their significance in prevention of viral infections. In addition, we provide the significance of microbes in different parts of the body upon viral infections. The future research will potentially focus on treatment of various viral diseases using probiotics or paraprobiotics as the rational adjunctive.

\section{Lung microbiota and respiratory infection}

As compared with the lower gastrointestinal part, the lungs contain about 10 to 100 bacteria per 1000 human cells that is relatively less bacterial biomass (Sze et al. 2012). A cystic fibrosis study reinforces that the gut and the lung microbiota develop at the same time after birth, and it is proved that there is a constant cross talk between these two areas (Marsland et al. 2015). The dynamic composition of the lung microbiome is determined by the incorporation through nutrition, temperature, and quality and quantity of the anti- 
inflammatory cells, elimination through cough, mucociliary clearance, innate and adaptive immunity, immigration through micro-aspiration and inhalation of microorganisms, and relative growth within its communities (O'Dwyer et al. 2016; Fanos et al. 2020). The lung is an organ that is continually exposed to microbiota either through inhalation or subclinical microaspiration from the beginning of life. The lung and airway microbiome have directly affected immunity against disease or can have an effect of altered local immunity/inflammation during the development of the disease. The upper respiratory tract and oropharynx, where microbes are found in abundance, are not eliminated through host mucosal defense and mucociliary clearance (Wilson and Hamilos 2014), able to reach deep in to the lung. Subclinical aspiration of oropharyngeal contents occurs universally in humans (O'Dwyer et al. 2016). Murine studies have demonstrated bacterial load in the lungs increases over the first 2 weeks of life, and the phyla of organisms found in the lung shifted from Gamma-proteobacteria and Firmicutes towards Bacteriodetes (Frank et al. 2010). The lung environment becomes rich in gut bacteria, such as Bacteroidetes and Enterobacteriaceae, called "more gut in the lung" (Fanos et al. 2020). Probiotics mainly colonize in the gut, but it has a fundamental impact on the systemic immune responses. It can also colonize and exert the immune responses at distant mucosal sites, including the lung (Tapiovaara et al. 2016; Baud et al. 2020). The study reported that probiotic $L b$. plantarum GG could colonize in the upper respiratory system, especially where the lymphatic system is available. Researchers have isolated probiotic $L b$. plantarum DSM9843 from the tonsil epithelium of six individuals after $8 \mathrm{~h}$ of per oral consumption of fermented oatmeal gruel enriched with $L b$. plantarum DSM9843 (Tapiovaara et al. 2016). Such developmental changes in the microbiota were associated with accumulation of $\mathrm{T}$ regulatory cell population that could promote tolerance to allergen challenge (Frank et al. 2010). Lung microbiota may specifically regulate lung immunity or the development of bronchial-associated lymphoid tissue against lung infection (O'Dwyer et al. 2016). A human can face different potent organisms, harmful particles, and gases during normal inhalation. Deposition of these harmful organisms, such as molds, bacteria, and viruses, occurs on the airway or alveolar surfaces. Some of these organisms range from less than 3 to $5 \mu$ that can only penetrate to the deep lung. Cilia and mucus layer prevent pathogens from entering the lung. Once they enter into the lung, the lung's defense mechanisms are activated through the activation of alveolar macrophage (Janssen et al. 2016). Alveolar macrophage with their cell surface receptor binds with the deposited particles, ingest, kill, and digest them. In addition, when the lungs are introduced with such serious infectious particles, white blood cells, especially neutrophils, increase in the circulation that helps to ingest and kill the pathogens. The lung microbiota can protect against respiratory infections with $S$. pneumoniae and $K$. pneumoniae, triggering the pulmonary production of granulocyte-macrophage colony-stimulating factor (GMCSF) through the stimulation on interleukin 17 (IL-17) and Nod2 (Mukherjee and Hanidziar 2018). Pro-inflammatory cytokine IL-17 is induced by $\mathrm{CD}^{+}$and $\mathrm{CD} 8^{+} \mathrm{T}$ cells of stromal, endothelial, and epithelial cells in response to lipopolysaccharides. IL-17 binds to cell receptors and activates neutrophils, AP-1, and NF-kB activity (Ryzhakov et al. 2011). IL-17 also induces endoplasmic reticulum stress and autophagy via inositol-requiring enzyme 1, inhibiting the reproduction of infectious virus (Kim et al. 2015). Nod-like receptors (NLRs) act as cytoplasmic receptors that support host defense mechanisms through stimulation of NFKB signaling. NF $k B$ controls the transcription of effector genes with the proinflammatory cytokine TNF- $\alpha$ and the neutrophil chemokine, IL-8. In reasonable condition, NFKB remains sluggish and binds with inhibitor molecule IKB in the cytoplasm. Upon stimulation, IKB is phosphorylated through IKK, sends the signal for ubiquitination, releases $\mathrm{NF} \kappa \mathrm{B}$ free from I $\mathrm{KB}$, and uncovers the nuclear localization sequence (NLS) that helps the NFkB p65/p50 heterodimer to travel into the nucleus and acts as a transcription factor at target promoter regions (Llewellyn and Foey 2017). NLRs protect against respiratory pathogen infection via neutrophil induction in the bone marrow, regulate circulatory neutrophil and inflammatory monocyte lifespan, support hematopoiesis, promote lymphoid follicle development, and stimulate adjuvant activity (Brown et al. 2017). Also, the gut microbiota plays a vital role in the response of the lung to bacterial infections. Studies on germ-free mice showed an increase in the morbidity and mortality during the acute pulmonary infection by $P$. aeruginosa, $K$. pneumoniae, and S. pneumoniae (Mukherjee and Hanidziar 2018). The World Health Organization as on January 30, 2020 has alarmed a public health emergency of international concern (PHEIC) due to novel coronavirus $(\mathrm{CoV})$ also termed as SARS-CoV-2 which causes severe acute respiratory syndrome. Lung infection with coronavirus involves disruptions of the epithelium in gas exchange areas and associated airways (Fanos et al. 2020). The epithelial cells of the alveoli serve as a SARS receptor with angiotensinconverting enzyme 2 (ACE2), digestion-related enzymes in human enterocytes. Coronaviruses are frequently varying the binding receptor and binding site during their progression (Feng et al. 2020). Viral infection induces alveolar macrophage to form multinucleated giant cells, monocytes, and dendritic cells to act against SARS-CoV. Elevated concentration of pro-inflammatory cytokines, including CXCL10 (IP-10), CCL2 (MCP-1), IL-6, and CXCL8 (IL-8) in serum, was evident when lung is exposed to SARS-CoV infection (Qian et al. 2013). Lung infection with SARS-CoV also leads to marked elevations in mRNA concentrations of interferon-b, interferon-1, CXCL10, CXCL11, and IL-6 (Zhaohui et al. 
2013). Out of several possible treatments of COVID-19, like nutritional, antiviral, anti-coronavirus, and miscellanea, medication with probiotics, especially bifidobacteria and lactobacilli, provides a significant chance of recovery (Fanos et al. 2020). Probiotics like Bifidobacteria or Lactobacillus has beneficial effects against influenza virus infection in the respiratory tract (Zelaya et al. 2016). Probiotic consumption improves the level of type I interferons, antigen-presenting cells, NK cells, and T and B cells in the lungs' immune system. Probiotic administration can also improve the pro- and anti-inflammatory cytokines, helping to clear the viral infection by minimizing the cell damage in the lungs (Baud et al. 2020). This suggested mechanisms also can be manifested to prevent the complications regarding COVID-19. Recent studies suggest that the involvement of the gut in COVID-19 is even greater and more prolonged compared with the lung $(\mathrm{Xu}$ et al. 2020).

\section{Nasopharynx microbes}

Nasopharynx serves as the predominant niches of various types of both commensals and pathogenic microbiota (Lemon et al. 2010). Microbes vary from smoker to nonsmokers, healthy to unhealthy, and aged versus neonatal in terms of membership and distribution (Charlson et al. 2010). Numerous investigations discovered that the nasal microbiome of healthy people is fundamentally composed of the phyla Actinobacteria, Bacteroidetes, Firmicutes, and Proteobacteria with the genera of Bifidobacterium, Propionibacterium, Corynebacterium, Dolosigranulum, and Moraxella being prevalent (Huffnagle et al. 2017; Kumpitsch et al. 2019). Numerous pathogenic species, including Streptococcus pneumonia, Haemophilus flu, Moraxella catarrahlis, Staphylococcus aureus, and Neisseria meningitidis, exist in the nasopharynx of apparently healthy people (Allen et al. 2014). Like pathogenic bacteria, some viruses, including rhinoviruses, enteroviruses, coronaviruses, and adenoviruses, have been found in asymptomatic infected people. The Human Microbiome Project's metagenomic studies could advance explicitly distinguish the significant organisms as $P$. acnes, $C$. accolens, $C$. kropenstedtii, S. aureus, and S. epidermitidis in the nasopharynx (Anon 2012). Among bacteria, $H$. influenzae was the most dominating bacterium, which together with $S$. pneumoniae and M. catarrhalis makes up the human nasopharynx microbiome (Bisgaard et al. 2007).

In the presence of $S$. pneumoniae, M. catarrhalis, and H. influenzae, either alone or in a mixture of these organisms, can altogether colonize blood eosinophil and increase $\operatorname{IgE}$ counts in youngsters at 4 years old (Bisgaard et al. 2007). Any infections of the upper respiratory tract lead to elaborate connections between bacterial pathogens and viruses, both synergistic and competitive. Microorganisms in the upper respiratory tract can change bacterial adherence, bacterial colonization, and host immune response. An investigation of the nasopharyngeal microbiota of kids with severe bronchitis demonstrated microbial movements relying upon the viral disease human rhinovirus (HRV) (Heinonen et al. 2016), respiratory syncytial infection (RSV) (Mejias et al. 2013), or cocontamination. The lung microbiota in chronic obstructive pulmonary illness (COPD) patients and healthy people during a rhinovirus challenge demonstrated massive changes after infection (Huang et al. 2017). The mucus layer present in the nasopharynx assists in humidifying the breathed air and traps the entered microorganisms or any foreign molecule (Kumpitsch et al. 2019). This contaminated mucus here and there is passed out through mucociliary clearance (Bustamante-Marin and Ostrowski 2017). Strangely, commensal organisms with immunomodulatory properties are fit for initiating the host's immune reactions and fast protection against pathogens (Michael and David 2013). Probiotic Lactobacillus GG, or in the combination of Lactobacillus GG with other probiotics, was shown to reduce the occurrence or risk of URI in children (Kumpu et al. 2012).

The human nose and upper respiratory tract efficiently hold the pathogen through invading immunogenic particles and droplets. The pathogen detected by mucosal layers of the gastrointestinal tract (GI), respiratory, urinary, and genital tracts functions as the body's immunologic system (Zhang et al. 2018). The human nose is covered by type 1 mucosal layer consisting of a single layer of epithelial cells, antigenpresenting cell, goblet cells, and specialized lymphoid organs similar to the gastrointestinal tract. After attachment, the pathogenic foreign particle that activates the local mucosal immune system even in the upper respiratory tract especially invades into the lung. Hua et al. (2018) demonstrated that the nasal exposure to coronavirus in the nose and upper airways can immunologically prepare the lungs for more rapid initiation of an innate and adaptive immune response against homologous and heterologous infection. The immune system plays a crucial job in treating severe acute respiratory coronavirus by changes in peripheral blood $\mathrm{T}$ lymphocyte subsets and contributes to understanding the disease diagnosis and treatment (Lin et al. 2020). Also, overproduction of cytokines and chemokines, activation of $\mathrm{T}$ helper cell-mediated immunity and host inflammatory response, was observed during the acute phase of SARS infection (Russell et al. 2020).

\section{Gut microbe interaction and immune modulation}

The gut is the key habitat where most of the microbes stay in the host symbiotically. In the gut, microbiota plays an indispensable role in maintaining intestinal homeostasis (Kerry 
et al. 2018). The gut microbiome includes different microbial communities, not restricting to, of bacteria, viruses, and fungi (Shi et al. 2017). The human gut microbiome consists of around 1000 different species of microbes and varies densities from $10^{4}$ to $10^{5}$ bacteria per millimeter of the digestive tract in the small intestine and $10^{11}$ bacteria per gram of luminal content of the colon (Thomas et al. 2017). The composition of the microbiome may differ from person to person, and it depends on environmental changes and genetic inheritance (Harmsen and de Goffau 2016). In sound people, the microbiome principally comprises of four gatherings of microscopic organisms: Firmicutes, Bacteroidetes, Proteobacteria, and Actinobacteria (Gu et al. 2013; Seedorf et al. 2014), in which the two phyla Firmicutes and Bacteroidetes represent $90 \%$ of gut microbiota. Additionally, for the most part, the dominating phyla of the gut are Bacteroides and Firmicutes, followed by Proteobacteria and Actinobacteria (Rinninella et al. 2019). In the symbiotic relationship between microbiota and the host, both are mutually beneficial (Parker et al. 2018). Microbiome utilizes the space, nutrient, and breeding environment from the human gut (Chang and Kao 2019). In turn, intestinal microflora helps in carbohydrate fermentation, synthesizes vitamins, and downregulates the intestinal permeability (Kau et al. 2011). The gut microbiota acts as a defense barrier and helps to modify the intestinal immune system. The lower tract microbiome is influenced by various environmental factors. Thus, the cooperation amongst the microbiome and intestinal immune system is indispensable to preserve intestinal homeostasis. When this homeostasis is exhausted by means the balanced gut microbial community change, dysbiosis causes intestinal diseases ( $\mathrm{Na}$ et al. 2017; Chang and Kao 2019). Studies revealed that the accelerated microbial colonization in the neonatal gastrointestinal tract performs a crucial role in the growth of the gut immune system. The gut microbiome exhibits competition against pathogen binding, their colonization, survival, and direct killing by their metabolites (e.g., organic acid, antimicrobial compounds), and increasing the gut-associated immunity. The probiotic oral administration protects against infection in distant gut mucosa like bronchi and urogenital mucosa (Hao et al. 2011; Barbieri et al. 2017). The risk of Salmonella enterica serovar Typhimurium contamination can be minimized by oral administration of probiotics inducing phagocytic and microbicidal action of macrophages (Galdeano et al. 2011). According to Galdeano et al. (2011), the cytokines released by the probiotic act on immune cells inaccessible from the digestive tract. With the production of a specific antibody, probiotics can stimulate the systemic immune response. A sufficient amount of probiotics can stimulate an innate and adaptive immunity of the host. Gut microbiota also has its long-distance health impact on the heart, liver, kidney, and lung immunity (Marsland et al. 2015; Enaud et al. 2020). In the gut-lung axis, distal (gut) immune modulation during respiratory disease is mediated by the gut microbiota. The healthy gut microbiome can alter the gut immunity as well as the lung immunity by their gutlung axis (Fanos et al. 2020). During airway infection of the respiratory tract, body's commensal organisms stimulate the immune response to the local (lung) and distal (gut) sites, considered as gut-lung axis, where gut microbiota modulate pulmonary immune system during this infection (Budden et al. 2017). The gut-lung axis is assumed to be bidirectional, meaning via the blood and lymphatic system where the microbial metabolites endotoxins can impact the lung when inflammation arises; also it can influence the gut microbiome. By this mechanism, there is a possibility of novel SARS-Cov2 that might also affect the alteration of the gut microbiota (Dhar and Mohanty 2020). Gut microbiota showed to involve in many respiratory disease modulation of the lung (Taylor et al. 2016). Probiotics showed significant microbial killing properties through alveolar macrophage, neutrophils, natural killer cells, and increased levels of pro-inflammatory cytokines like TNF- $\alpha$ and IL-6 in the lung (Vieira et al. 2016; Belkacem et al. 2017). The anti-inflammatory cytokines (such as Treg cells and IL-10) also increase with increasing pro-inflammatory cytokines in the lung of infected mice (Khailova et al. 2013). The most important way is that the lymphatic system lies in between the lungs and the intestine. Commensals, their body parts (e.g., lipopolysaccharide), and metabolites (e.g., short-chain fatty acids) translocate through the mesenteric lymphatic system from the gut to the lung using the systemic circulation and regulate the lung immunity (Trompette et al. 2014; Bingula et al. 2017). A recent study revealed that tissue-repairing innate lymphoid cells could migrate from the gut to the lungs, in response to an inflammatory immune response upon IL-25 (Huang et al. 2018). A study reported that $K$. pneumoniae infection was downregulated by the consumption of Bifidobacterium longum in mice. Looft and Allen (2012) concluded the reduced level of Lactobacilli and Lactococci and upregulation of Enterobacteriaceae in the gut lumen during influenza infection study in a clinical model.

\section{Mucosal immune response}

Dysbiosis of the host immunity can stimulate the body's immune system, i.e., immune organ, soluble cytokines, and cell receptors, and the main backbone of the immune defense. The communication between microbiota and environmental factors affects mucosal immunity (Neish 2014). The mucus layer present on the surface of the gastrointestinal tract, respiratory tract, vaginal tract played the first line of defense, where immunoglobulin A antibody acts as the first line of mucosal immunity (Corthesy 2013). Mucins act as a barrier function of mucus immunity. The foreign particle or pathogen once crosses the mucociliary barrier able to get contact with several soluble antimicrobial peptides present in the mucus, such as 
lysozyme, lactoferrin, collectin, and defensins, produced by immune cells of the respiratory tract. These antimicrobial peptides are involved in direct killing of the pathogen or pathogen inhibition through opsonization or recruitment of other inflammatory cells (Das and Thakur 2015; Boyton and Openshaw 2002). Pathogen infection of mucosal epithelial cells introduces monocytes, macrophages, granulocytes, B cells, natural killer cells, and dendritic cells. Initiation of these safe cells relies upon different pattern recognition receptors (PRRs). PRRs including Toll-like receptors (TLR) and nucleotide-binding oligomerization domain-containing protein 2 (NOD-2), C-type lectin-like receptors (CLRs), and cytosolic DNA sensors activated intracellular signalling induce immune responses, through pro- and/or anti-inflammatory or regulatory and/or antiviral chemokines' direct immunogenic responses (Akira et al. 2001; Ausubel 2005; Chaudhuri and Sabroe 2008; Hooper and Macpherson 2010). Pathogen destruction through macrophage and dendritic cells also take part in the innate respiratory mucosal immune system. Alveolar macrophage immediately eliminates the pathogen by emitting NO and reactive oxygen species. Dendritic cells (DCs) assist with perceiving and dispense with the pathogen from various perspectives. DCs play a significant part in viral clearance from the lungs by initiating antiviral $\mathrm{CD} 8^{+}$cytotoxic $\mathrm{T}$ cell response in the lymph nodes (Ho et al. 2011). Dendritic cells are proficiently phagocytized the invading pathogen through transepithelial dendrites (Farache et al. 2013). Dendritic cells also help to block and transcytosize the pathogen through epithelial goblet cells and M cells. Invading antigens are transcytozed through $\mathrm{M}$ cells to the subepithelial APCs. APCs send the signal to the T cell region of the mucosa-associated lymphoid tissue (MALT) for processed antigen presentation to the $\mathrm{B}$ cell. The $\mathrm{B}$ cell generates surface immunoglobulin $\operatorname{IgA}$ positive $\left(\operatorname{IgA}^{+}\right) \mathrm{B}$ cells. Antigenstimulated $\mathrm{T}$ cells and cell surface immunoglobulin enter into the systemic circulation through the lymph nodes. During intracellular immunoglobulin-mediated transport, a virus may be neutralized through it (Das and Thakur 2015). Cytokines derived from epithelia, like TGF-beta, IL-25 and IL-33, play a critical role in the activation of a $\mathrm{Th} 2$ or $\mathrm{T}$ regulatory mucosal immune response. Severe lung damage with RSV increased neutrophil infiltration and upregulation of TNF- $\alpha$, IL-13 producing $\mathrm{CD}^{+}$cells in the lung (Stokes et al. 2013). Infection with RSV also upregulate the mucus production due to an increased level of IL-17, a pro-inflammatory cytokine secreted by the activated $\mathrm{T}$ cells in the lung (Chen et al. 2003). Probiotic organisms also help in maturation and activation of the mucosal immune system (MIS) by various signal networks mediated by their secreted metabolites, such as organic acid, short-chain fatty acids (SCFAs) (Topping and Clifton 2001; Mcdermott and Huffnagle 2014), and antimicrobial compounds termed bacteriocins (Galdeano et al. 2019). Several viruses cause respiratory infection to humans (Marsland et al. 2015). Probiotic bacteria also could bind to an invading virus, thus inhibiting virus attachment to the host-cell receptor (Salminen et al. 2010). Probiotic medication helps to fortify mucosal immunity and provide restriction against respiratory viral infection (Marsland et al. 2015).

\section{Probiotic as immune enhancers}

Probiotics exert several health beneficial effects to the host by several potential systems through the local immunity (by keeping up gut wellbeing and gut wall integrity) and systemic immunity (by enhancing specific and non-specific immune system). The application of probiotics is efficient and competent for several ailments, including virus infection (Kanauchi et al. 2018). Over a century ago, Nobel Prize winner Elie Metchnikoff performed a series of trials showing that ingesting lactic acid-producing microbes improves illness like digestive and respiratory tract disorders (Gordon 2008). Probiotics modulate the host's innate immune system by enhancing phagocytic activity, leucocytes (polymorphonuclear and monocytes), and expression of some receptors (CR1, CR3, FccRI, and FcaR) that are associated with phagocytosis, and increases the microbicidal function of neutrophils (Hao et al. 2011). The number and the activity of natural killer (NK) cells are also significantly improved in the blood (Grudzien and Rapak 2018). Toll-like receptor (TLR) signalling by commensal organisms exhibits a significant effect for preserving the host's intestinal homeostasis by enhancing gut barrier function and improving the local immune response (Belkaid and Hand 2014).

Probiotics also can induce APCs derived pro- and antiinflammatory cytokine (for example, IL-10, IL-12, IL-17, $\mathrm{TNF}-\alpha$, interferon- $\alpha$ ) production against foreign particles through activation of adaptive immunity. Intestinal inflammation regulatory pro-inflammatory cytokines, chemokines and their receptors are inhibited by anti-inflammatory cytokine IL10 , produced by different immune-activated cells (Azad et al. 2018). Probiotics provide two different immunomodulatory effects: one is the immunostimulatory effect, which activates IL-12 production, induces NK, Th1, and Th2 cells, and acts against infection and allergy; and another type is immunoregulatory effect, which induces IL-10 and Treg cell activation by Th2, DCs, B cells, and monocytes for adaptive immunity of the host (Chiba et al. 2010) (Fig. 1). A recent animal and human clinical study showed the increased level of IFN-g, IL-2, tumor necrosis factor (TNF)- , serum IgA, and IgAsecreting cells in response to immune function of Lactobacillus or Bifidobacterium strains (Zhang et al. 2018).

With the enhancement of gut immunity, probiotic consumption may also decrease the risk or can modify respiratory health infection (Wang et al. 2016). Probiotics stimulate lung immunity by enhancing $\mathrm{T}$ regulatory response in the airway. 


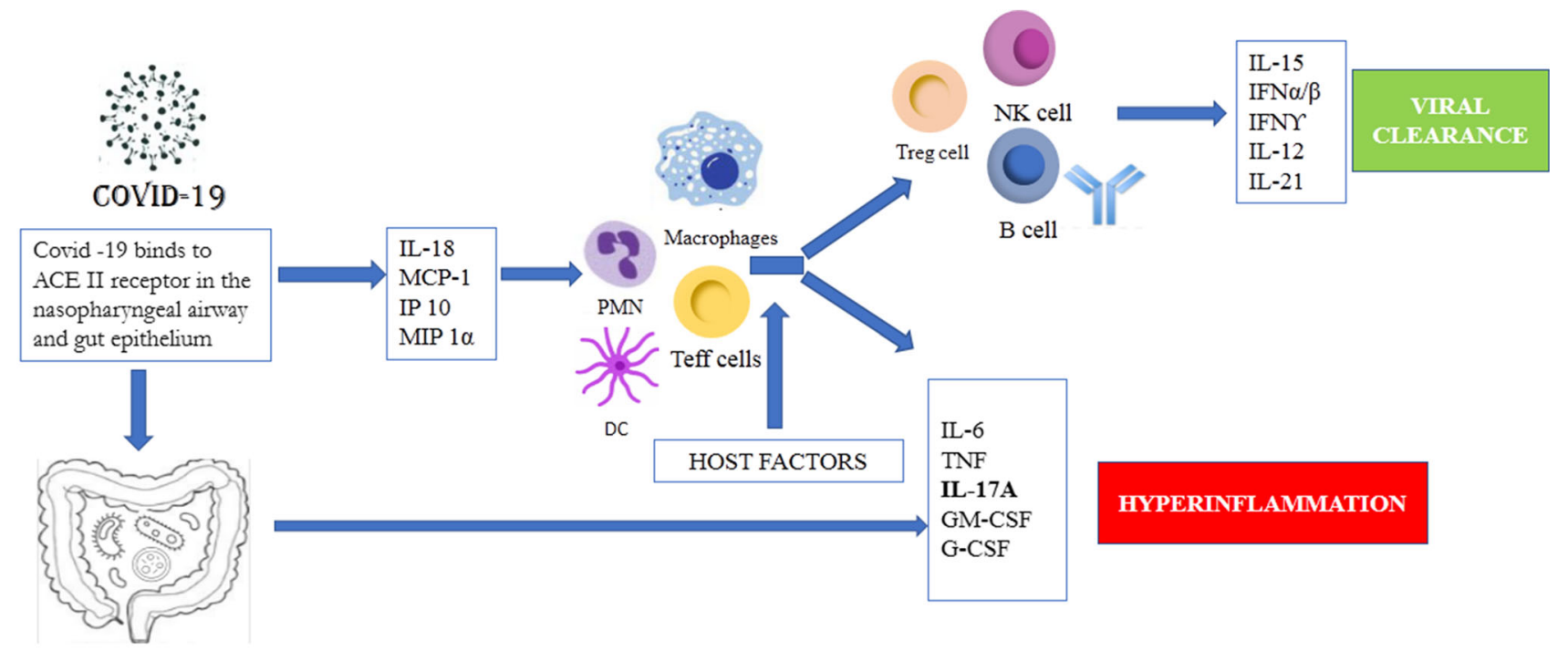

Gut microbiome dysbiosis

(IL-17 production)

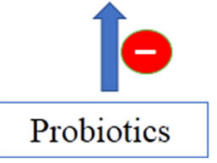

Fig. 1 The mechanism involved upon host infected by COVID-19. Pro inflammatory cytokines and interferons are released, and viral cellular translation is supressed to induce viral clearance as a part of the host immune response and an antiviral state in adjacent epithelial cells. Viral clearance occurs in lung and gut epithelium depending on the immune status of the host. However, probiotic consumption improves

The LABs directly enter into the circulation from the gut to the lung and exerts different immunomodulatory action. Oral consumption of lactobacilli can modulate cytokine profiles systemically (Mortaz et al. 2013). Another study showed that Lactobacillus GG and Lb. casei strains, Shirota $(L c S)$ and DN114001, can prevent and treat the microbial infections in the gastrointestinal and respiratory tract with influenza (Mortaz et al. 2013). A community study in both elderly and kids has shown that probiotics Lb. paracasei, Lb. casei 431, and $L b$. fermentum PCC may decrease the occurrence, duration, and symptoms of flu and respiratory tract infections by increasing the level of IFN-g in the blood and SIgA in the gut (Zhang et al. 2018). The IFN-g induces bactericidal function of macrophages, induces B cell-opsonizing activity, and increases complement-fixing antibodies that lead to adaptivemediated immunity (Marshall et al. 2018). Consumption of Bifidobacterium and Lactobacillus was found to improve the upper and lower respiratory tract infections in children and young population (Rautava et al. 2009; Smith et al. 2013). Consumption of Bifidobacterium breve-augmented antiinfluenza IgG could successfully protect respiratory tract infections in mice against influenza (Yasui et al 1999).

Compared with the healthy adults and the elderly, the immunocompromised elderly population contain reduced diversity and a lower number of the intestinal microbial community inflammation by regulation of immune response in gut through various signalling pathways and helps improve gut dysbiosis caused by SARS$\mathrm{CoV} 2$ and hastens recovery in patients. ACE II, angiotensin-converting enzyme II; PMN, polymorphonuclear granulocyte; DC, Dendritic cells; $T_{\mathrm{EFF}}$ cell, $\mathrm{T}$ effector cell; $T_{\text {reg }}$ cell, regulatory $\mathrm{T}$ cell; NK, natural killer

of Firmicutes, Bifidobacteria, Clostridium, Faecalibacterium, Prausnitzii, and Blautia coccoides-Eubacterium rectal and higher occurrence of Enterobacteriaceae and Bacteroidetes (O’Toole and Claesson. 2010). Firmicutes and Bacteroidetes symbolize $93 \%$ of the total intestinal microflora in a healthy individual (Rondanelli et al. 2015). The number of intestinal organisms and its composition reduce with increasing the age, with induced numbers of facultative anaerobes and Gramnegative bacteria (mainly Enterobacter), and decrease in the mucosal architecture. This microbial composition shifting occurs due to living environment, malnutrition, health condition, and different drug administration such as antibiotics and nonsteroidal anti-inflammatory drugs (NSAIDs) (Mäkivuokko et al. 2010). The $16 \mathrm{~S}$ rDNA sequencing of 18 older adults taking NSAIDs showed the changes in the significant microbial phyla, such as a lower number of Firmicutes and an increasing number of Bacteroidetes (Mäkivuokko et al. 2010). The intestinal transit time also depends on the increasing age and health condition. In the case of immunocompromised subject, the intestinal transit time is more, and fecal bacterial cell mass is less compared with the healthy people (Patel et al. 2013). Therefore, variation in the microbial arrangement in the intestinal lumen may lead to decreased immune system function and a higher incidence of gastrointestinal infections in the elderly than in the young. The main immunological 
changes associated with aging involve reductions of efficiency of the immune responses mediated by $\mathrm{B}$ and $\mathrm{T}$ cells (Rondanelli et al. 2015), because the number of lymphocytes in the peripheral blood along with $\mathrm{CD}^{+} \mathrm{T}$ and $\mathrm{CD}^{+} \mathrm{T}$ decreases with the increasing age (Pu et al. 2017).

Aging affects both innate and adaptive immune responses. Elderly appearances lack immunological ability like a decrease in phagocytosis, alteration of cellular migration, changes in cell populations and numbers, and decreased antibody production that reduced efficacy to resist infection (Patel et al. 2013). Appropriate probiotics significantly can boost immunity in the elderly (Hamilton-Miller 2004). Administration of a modified diet with proper nutritional food habits may modulate the microbial community. The use of probiotics is safe and represent beneficial provision to prevent or treat various elderly disorders (Blaut et al. 2006). The efficiency of treatment of older adults with Bif. lactis DN173010 and Lb. casei Shirota is responsible for the production of short-chain fatty acids like butyric acid, propionic acid, lactic acid and decreased the colonic $\mathrm{pH}$ value that increased the peristalsis in the colon which is capable of decreasing the intestinal transit time (Patel et al. 2013). A 12-week study of oral administration of the yogurt supplemented with $L b$. paracasei N1115 can significantly reduce the risk of upper respiratory tract infection (URTI) in the mid-aged and elderly by stimulation of the $\mathrm{T}$ cell immunity, and the frequency of URTI in the subjects compared with the control group (Pu et al. 2017). Administration of a fermented dairy product containing the probiotic strain $L b$. casei DN-114 001 could decrease the duration of common infectious diseases (CID) of the airways, especially in rhinopharyngitis in the elderly in comparison with the control group (Guillemard et al. 2010). Probiotic Lactobacillus GG helps in significant modulation of allergic reaction related to atopic eczema (Ozdemir and Goksu Erol 2013). Harata et al. (2010) studied that intranasal spray of Lactobacillus GG could regulate respiratory immune system in mice against H1N1 influenza virus infection. Probiotics are also responsible for reducing the risk of chances of ventilatorassociated pneumonia; other respiratory infection in healthy and diseased person and 40-60\% virus infected chronic obstructive pulmonary diseases (COPD) are prevented by administration of probiotic (Mortaz et al. 2013).

Probiotic consumption decreases the risk of respiratory tract infection in children (Araujo et al. 2015). Typical upper respiratory tract infection and certain types of influenza include the following: tonsil, pharynx, larynx, and sinuses (Eccles et al. 2007; Thomas and Bomar 2020). Indications of critical upper respiratory tract infections can include runny nose, headache, cough, nasal congestion, sore throat, lowgrade fever, sneezing, and facial pressure (Van Riel et al. 2006). The utilization of probiotics fundamentally diminishes the danger of the basic cold and lessens the duration of the manifestations of respiratory tract infections (Wang et al.
2016). In addition, probiotics showed a significant role to in competitively colonizing in the gut to exclude pathogens, modulating the gut barrier function and permeability. It has been shown earlier that probiotics can increase the neutrophil, leukocyte, and natural killer cell counts and activity, as explained earlier. A study showed that probiotics modulate the expression of interleukin (IL)-10 and decrease the inflammatory cytokine expression, such as tumor necrosis factor-a, IL$1 \mathrm{~b}$, and IL-8 (Oliva et al. 2012), increase salivary immunoglobulin A levels and produce bacteriocins, and ultimately exert the antimicrobial activity (Fooks and Gibson 2002). A meta-analysis showed that administration of Lb. rhamnosus GG prevented RTIs (Liu et al. 2013). Another meta-analysis evaluated the effectiveness of probiotics on the duration of respiratory illness episodes in children grouped with adults and restrained to the examinations using Lactobacillus and Bifidobacterium strains (King et al. 2014). Tabbers et al. (2011) showed curing of nosocomial infection by using Bifidobacterium animalis subsp. lactis strain BB-12. BioGaia's strain L. reuteri DSM 17938 has been shown to protect against upper respiratory tract infection and gastrointestinal problems in children aged 6 months to 3 years old (Gabryszewski et al. 2011).

\section{Zinc bioavailability and immune system}

Zinc in large portion of the cell's metabolic process is utilized as a fundamental cofactor for metallo-enzymes. It is found essential for membrane integrity, DNA synthesis, and cell multiplication, particularly the immune cells (Hojyo and Fukada 2016; Read et al. 2019). Zinc additionally assists with improving the host's reaction to numerous infections and assumes a significant role in maintaining the host homeostasis (Fukada and Kambe 2014). Zinc administration was suggested to improve the T cell-mediated function, an increment in IL-2 mRNA levels, and to reduce production of the proinflammatory cytokine, DNA, TNF- $\alpha$, and lipid oxidation (Barnett et al. 2010). The unavailability of zinc is correlated with the hindered cellular immunity and its deficiency has been observed to reduce the number of $\mathrm{B}$ and $\mathrm{T}$ lymphocytes, particularly $\mathrm{CD}^{+}$, and activation of Th1 cytokine. Zinc also stabilizes the cell membrane, and its deficiency disrupts the intestinal mucosa, reduces brush border enzymes, and increases mucosal permeability, macrophage function, and the intestinal secretion of water through the cytokine production, intracellular killing, and phagocytosis (Shankar and Prasad 1998).

A meta-analysis of oral zinc supplementation in patients' with acute respiratory infections observed reduced symptoms and duration of common cold infection (Science et al. 2012). Another study on supplementation of zinc in kids having pneumonia indicated vital reduction of sick conditions 
(Rerksuppaphol and Rerksuppaphol 2019). Zinc helps to inhibit viral protease and interferes in physical processes such as virus attachment, infection, and coating (Read et al. 2019). Respiratory epithelial barrier contains tight junction and adhesion junction, where E-cadeherin and $\beta$-catenin act as the major transmembrane molecules. Deficiency of zinc leads to proteolytic degradation of E-cadherin and $\beta$-catenin molecules leading to increased leakage across the upper and alveolar lung epithelial cell (Gammoh and Rink 2017). Zinc depletion also induces abandoned neutrophil migration around the disrupted tight junction with inducing chemokine production, ultimately causing lung disease. Zinc can inhibit several viral respiratory tract infections, including herpes simplex virus (HSV) and the non-enveloped rhinovirus (Suara and Crowe 2004). Respiratory syncytial virus (RSV) is the most significant viral agent for acute respiratory tract infection (ARI), also prevented by zinc salts by preventing cell-to-cell spread in in vitro culture conditions. Zinc supplementation with vitamin A is effective in thwarting acute respiratory disease (ARI), just as diarrhea (Cuevas and Koyanagi 2005). Supplementation of 10-20 mg zinc sulfate/day showed a significantly reduced risk of treatment failure to severe acute lower respiratory tract infection among children in India (Basnet et al. 2012). Another study revealed that increasing plasma zinc levels with daily intake of $10 \mathrm{mg}$ zinc gluconate could decrease the incidence of acute lower respiratory tract infection (Overbeck et al. 2008). Zinc is reported to inhibit RNA-dependent RNA polymerase activity of several viruses including coronavirus, arterivirus, rhinovirus, and hepatitis $\mathrm{C}$ virus (Kar et al. 2019). In order to deliver zinc in highly bioavailable form, probiotic strains $L b$ fermentum SR4 and $L b$ rhamnosus GG (LGG) were studied for their ability to accumulate zinc. The results demonstrated that higher bioavailability of $\mathrm{Zn}$ was chelated by SR4 and LGG up to $57 \%$ and $48 \%$, respectively, when compared with the commercially available inorganic (ZnSo4) and zinc gluconate forms (Lule et al. 2020). te Velthuis et al. (2010) revealed that the combination of $\mathrm{Zn}^{2+}$ and pyrithione (PT) at low concentrations inhibits the replication of SARS coronavirus (SARS-CoV). A study showed consumption of up to $50 \mathrm{mg}$ zinc per day suppresses pandemic COVID-19 viral replication by improving the host's resistance against the viral infection (Razzaque 2020). However, zinc maintains direct antiviral features, through activation of innate and acquired (humoral) antiviral responses (Maywald et al. 2017; Read et al. 2019).

\section{Role of vitamin D to fight against viral infections}

Vitamin D, which is predominantly present in the skin, is significant in calcium reabsorption in the intestine and kidney by activating transcellular calcium transport. The active form of vitamin D, 1,25-dihydroxyvitamin D (1,250HD, also called VDR) hormone regulates gene expression especially in immune function and inflammation (Gunville et al. 2013). Vitamin D functioning of immune system helps maintain tight junctions, gap junctions, and adherens junctions. Viral disease affects the junction integrity thereby increasing the rate of infections in the host (Rossi et al. 2020). Deficiency of vitamin D may reduce 25-hydroxyvitamin D (25OHD) levels thereby affecting the host. Probiotic bacteria have been characterized to produce vitamins and positively influencing the composition of the gut microbiota and immune system (Hill et al. 2014). Probiotic bacteria, mostly belonging to the genera Lactobacillus and Bifidobacterium, confer a number of health benefits, by acting against vitamin delivery and protecting from deficiency (Jayawardena et al. 2020). The higher dietary intakes of fat-soluble vitamins, especially vitamin $\mathrm{D}$, are associated with reduced microbial diversity of alphaProteobacteria predominantly comprising human pathogens (Steinert et al. 2020).

Studies have demonstrated the significances of vitamin D directly or indirectly in combatting the infection caused by viruses such as rotavirus (Zhao et al. 2019), dengue (Martinez-Moreno et al. 2020) and influenza (Urashima et al. 2010). In COVID-19, rise in case fatality rates (CFR) in oldsters may be due to the reduction in serum 25OHD concentrations with age (Razdan et al. 2020). The reduced production of vitamin D is a result of lower levels of 7dehydrocholesterol in the skin due to the less time spent in the sun. Immunomodulatory effects of vitamin D acts on both the innate and adaptive immune systems thereby reducing risk of infection and fatality. In COVID-19 patients, the innate immune system generates pro-inflammatory and antiinflammatory cytokines in response to viral and bacterial infections (Huang et al. 2020). Vitamin D is a modulator of adaptive immunity. The 1,250HD suppresses $\mathrm{T}$ helper cell type 1 (Th1)-mediated responses, by repressing production of inflammatory cytokines IL-2 and interferon gamma (INF $\gamma)$ (Lemire et al. 1985). Additionally, 1,25OHD promotes cytokine production by the T helper type 2 (Th2) cells, which helps enhance the indirect suppression of Th1 cells by complementing this with actions mediated by a multitude of cell types. Furthermore, 1,25OHD promotes induction of the $\mathrm{T}$ regulatory cells, thereby inhibiting inflammatory processes. COVID-19 infection initiated increased secretion of the Th2 cytokines (e.g., interleukins 4 and 10) that suppress inflammation, which differs from SARS-CoV infection (Huang et al. 2020). SARS-CoV and MERS-CoV differ from CoV infections by producing storms of pro-inflammatory cytokine.

This section defends the role of higher 25OHD concentrations in reducing risk of infection and death from acute respiratory tract infections (ARTI), including $\mathrm{CoV}$ and pneumonia. The peak season for ARTIs is generally when 25OHD concentrations are lowest. Thus, vitamin D supplementation may 
Table 1 List of probiotics and their mode of action in stimulating immune response against viral infections

\begin{tabular}{|c|c|c|c|}
\hline Microbe & Type of infection/virus & Mode of action & References \\
\hline Lb. plantarum NCIMB 8826 & RSV, pneumovirus, & TLR-dependent inflammatory response & Al Kassaa et al. 2014 \\
\hline Lb. casei $\mathrm{DN}-114001$ & RTI, rhinopharyngitis, influenza & Enhanced defensin expression and innate immunity & Guillemard et al. 2010 \\
\hline Lactobacillus rhamnosus M21 & Pneumonia, influenza & Increases interferon- $\gamma$ and interleukin- 2 & Song et al. 2016 \\
\hline Bifidobacterium infantis BB-12 & URTI & IL-17 inhibitory effect & Smith et al. 2013 \\
\hline Bifidobacterium animalis & URTI & Prevents replication on virus, anti-interleukin-17 & Smith et al. 2013 \\
\hline Lactobacillus plantarum & Gastroenteritis coronavirus (TGEV) & Diminishes granulocyte, reduces virus recovery & Yang et al. 2017 \\
\hline Lactococcus lactis JCM 5805 & RTI, common infectious disease & Activates plasmacytoid dendrtitic cell & Kokubo et al. 2019 \\
\hline Lactobacillus plantarum CRL1506 & Gastroenteritis coronavirus (TGEV) & Diminish inflammatory-mediated tissue damage & Yang et al. 2017 \\
\hline Bacillus subtilis OKB105 & Gastroenteritis coronavirus (TGEV) & Inhibits viral adherence by competitive inhibition & Wang et al. 2017 \\
\hline
\end{tabular}

be started through vitamin-producing probiotics on a regular basis to raise $25 \mathrm{OHD}$ concentrations above $40-60 \mathrm{ng} / \mathrm{ml}$. However, for treatment of patients infected with COVID-19, a higher dose might be useful (Jeyaraman et al. 2020). Further study on vitamin supplementation by probiotics needs to be evaluated using a large population of healthy individuals comprising equal number of male and female volunteers. This will also enlighten the differences in immune response during infections. On 23 March 2020, Dr. Tom Frieden, Former Director, Center for Disease Control and Prevention, has proposed using vitamin D to combat the COVID-19 pandemic (https://www.foxnews.com/opinion/former-cdc-chief-tomfrieden-coronavirus-risk-may-be-reduced-with-vitamin-D).

\section{Probiotics and control of viral infections}

The immune-suppressed patient encounters dysbiosis in the gut microbiota thereby leading to the accumulation of pathogens in the intestinal tract. Infections caused by intestinal bacteria are among the most difficult and challenging to treat, with great potential to become life threatening. In the case of viral infections in humans, respiratory tract epithelium is an entry gate. The first level of protection in the host is by tenacious mucus through motion of the cilia in the columnar epithelium, secretory immunoglobulin A limits in the respiratory tract secretion. The influence of viral infection on the dendritic cells (DC) leads to a cascade of reactions with an activation of $\mathrm{CD} 4^{+}$and $\mathrm{CD} 8^{+}$cells and subsequent development of specific $\mathrm{T}$ and $\mathrm{B}$ cell-mediated immunity.

Probiotics, besides being beneficial bacteria, also possess antiviral activity. Probiotics are chosen as alternatives as they act as natural immune enhancers (Lakshmi et al. 2013). Probiotics and their metabolites may also indirectly interfere with the virus by altering the state of cells, stimulating innate and/or adaptive immunity. They exert antiviral activity by (1) direct probiotic-virus interaction, (2) production of antiviral inhibitory metabolites, and (3) stimulation of the immune system. Lactic acid bacteria (LAB) and their bacteriocins serve as antiviral agents (Al Kassaa et al. 2014). LAB are known to synthesize exopolysaccharides (EPS), which may confer health benefits to people such as immunomodulatory, antitumor, antibiofilm, and antioxidant activities. One such strain, Lb. plantarum CRL1506, upon oral administration demonstrated antiviral properties, through diminish inflammatorymediated tissue damage (Yang et al. 2017). Analysis of $L b$. plantarum metabolites showed major presence of sugars, thus indicating the major antiviral active substances may be polysaccharides. Previous studies have also demonstrated colonization of the epithelium with the lactobacilli sterically hindered the adhesion of virus to the surface. Callahan et al. (1991) reported that sulfated exopolysaccharides inhibit the adherence of HIV to the target cells, thus blocking viral entry in to the host. Similarly, Bacillus subtilis OKB105 and surfactin have been found to have antiviral activity against TGEV entering the porcine intestinal epithelial cells by adsorbing virus particles and blocking viral attachment by competitive inhibition (Wang et al. 2017).

Probiotics and paraprobiotics of $L b$. plantarum or $L b$. reuteri against the pneumonia virus diminished granulocyte recruitment and expression of multiple pro-inflammatory cytokines and reduced virus recovery. This indicates the mechanism of action may be TLR independent (Gabryszewski et al. 2011). A clinical trial of $L b$. plantarum HEAL 9 and $L b$. paracasei 8700:2 in healthy individuals reduced the risk of acquiring common cold infections and pharyngeal symptoms (Berggren et al. 2011). A study conducted by Kokubo et al. (2019) showed Lactococcus lactis LC plasma affects plasmacytoid dendritic cell activation. This attenuates muscle degenerative genes and the concentration of fatigue-controlled cytokine transforming $\beta$-growth factor. Lb. rhamnosus M21 upon treatment for pneumonia in mice showed increased levels of interferon- $\gamma$ and interleukin-2, which are representative cytokines of type I helper T cells (Song et al. 2016) 
(Table 1). Application of probiotics has demonstrated clinical potential in animal experiments. Various strains of Lactobacillus spp. and Bifidobacterium spp. through oral or intranasal administration have shown suppression of infection symptoms against viral infections including influenza (Kawahara et al. 2015; Zolnikova et al. 2018). These decrease the virus load titers and increase $\mathrm{T}$ helper cells in the lung parenchyma. In another study, simultaneous administration of Lb. rhamnosus and Bif. lactis has increased IFN-y and interleukin (IL)-4, IL-10, and IL-6 in the bronchoalveolar lavage and activity of phagocytic cells (Gill et al. 2001; Di Cerbo et al. 2016). As a result, probiotics can cause destruction of viral nucleic acid and limit a virus replication. However, the question about probiotic properties, for a prevention or treatment choice against SARS, MERS, and COVID-19, remains open. Further research needs to be focused on the clinical trials for probiotic administration as an adjuvant therapy for the management of COVID-19 patients.

\section{Conclusions}

The safety of probiotics including lactobacilli and bifidobacteria has been demonstrated by numerous clinical studies. Current evidences show probiotics and probioticderived factors have promise for enhancing health benefits and regulation of host homeostasis, including immune health. Protection from viral infection has shown as a benefit of probiotic action. The probiotics exert their beneficial effects through modulation of host immune responses, maintain gut homeostasis and produce interferon thereby suppressing the virus induced cytokine storm. Although a few randomized controlled trials showed that administration of probiotics could thwart ventilator-associated pneumonia in COVID-19 patients, the efficacy in reduction of mortality remains uncertain. Lactobacilli and bifidobacteria have shown a promising beneficial effect and administration of them can overcome the gut dysbiosis induced by the SARS-CoV2 infection. Hence, it is reasonable to change the microflora with administration of probiotics and thus potentially improve the host immune status. Yet, the immune stimulation and cytokine expression is strain specific, and may vary according to consortia of the probiotic bacteria. It is likely that a novel and more targeted approach to modulation of gut microbiota as one of the therapeutic approaches of COVID-19 and its comorbidities will be necessary.

As probiotic research goes into the next stage, mechanism of each probiotic action is to be elucidated for effective clinical use. This leads to potential demand for personalized medicine. Future clinical trials may characterize baseline individual microflora and their genetic pattern of responses upon probiotic introduction, therefore revealing the potency of probiotic application in human disease prevention and treatment. In addition, as a part of translational and clinical research, biomarkers are to be identified for the evaluation of therapies, including probiotics in hosts. This indeed confirms that immune stimulation through probiotics potentially promote prolonged resistance to virus infections and diseases in humans.

Acknowledgments Authors would like to thank The Director, Dr KSMS Raghavarao, Council for Scientific and Industrial Research-Central Food Technological Research Institute, for facilities and encouragement to write the article. AS would like to thank Council for Scientific and Industrial Research for providing Nehru Post-Doctoral fellowship. MR would like to thank Indian Council of Medical Research for providing Research Associate fellowship. We acknowledge Dr. SVN vijayendra for his critical comments on the manuscript

Authors' contributions AS and PH conceived and designed the review. AS, MR, and PVR wrote the manuscript. PH analyzed data and supervise the work. All authors read and approved the manuscript.

Funding information This research was funded by the Council of Scientific and Industrial Research, India (EMR-2019- P90807).

\section{Compliance with ethical standards}

Ethical statement This article does not contain any studies with human participants or animals performed by any of the authors.

Conflict of interest The authors declare that they have no competing interests.

\section{References}

Akira S, Takeda K, Kaisho T (2001) Toll-like receptors: critical proteins linking innate and acquired immunity. Nat Immunol 2:675-680. https://doi.org/10.1038/90609

Al Kassaa I, Hober D, Hamze M, Chihib NE, Drider D (2014) Antiviral potential of lactic acid bacteria and their bacteriocins. Probiot Antimicrob Proteins 6:177-185. https://doi.org/10.1007/s12602014-9162-6

Allen KE, Koeppel AF, Hendley JO, Turner SD, Winther B, Sale MM (2014) Characterization of the nasopharyngeal microbiota in health and during rhinovirus challenge. Microbiome 2:22. https://doi.org/ $10.1186 / 2049-2618-2-22$

Anon (2012) Human Microbiome Project Consortium. Structure, function and diversity of the healthy human microbiome. Nature 486: 207-214. https://doi.org/10.1038/nature11234

Anon (2020a) Coronaviridae Study Group of the International Committee on Taxonomy of Viruses. The species severe acute respiratory syndrome-related coronavirus: classifying 2019-nCoV and naming it SARS-CoV-2. Nat Microbiol 5(4):536-544

Anon (2020b) Characterization of spike glycoprotein of SARS-CoV-2 on virus entry and its immune cross-reactivity with SARS-CoV $\mid$ Nature Communications [Internet]. Available from: https://www.nature. com/articles/s41467-020-15562-9

Araujo GV, Oliveira Junior MH, Peixoto DM, Sarinho ES (2015) Probiotics for the treatment of upper and lower respiratory-tract infections in children: systematic review based on randomized clinical trials. J Pediatr 91:413-427. https://doi.org/10.1016/j.jped.2015. 03.002

Ausubel FM (2005) Are innate immune signaling pathways in plants and animals conserved?. Nat Immunol 6:973-979. https://doi.org/ $10.1038 /$ ni1253 
Azad MDAK, Sarker M, Wan D (2018) Immunomodulatory effects of probiotic on cytokine profiles. Biomed Res Int 2018:80636478063610. https://doi.org/10.1155/2018/8063647

Barbieri N, Herrera M, Salva S, Villena J, Alvarez S (2017) Lactobacillus rhamnosus CRL1505 nasal administration improves recovery of Tcell mediated immunity against pneumococcal infection in malnourished mice. Benefic Microbes 8:393-405. https://doi.org/10.3920/ BM2016.0152

Barnett JB, Hamer DH, Meydani SN (2010) Low zinc status: a new risk factor for pneumonia in the elderly? Nutr Rev 68:30-37. https://doi. org/10.1111/j.1753-4887.2009.00253.x

Basnet S, Shrestha PS, Sharma A, Mathisem M, Prasai R, Bhandari N, Adhikari RK, Sommerfelt H, Valentiner-Branth P, Strand TA, Zinc Severe Pneumonia Study Group (2012) A randomized controlled trial of zinc as adjuvant therapy for severe pneumonia in young children. Pediatrics 129:701-708. https://doi.org/10.1542/peds. 2010-3091

Baud D, Agri VD, Gibson GR, Reid G, Giannoni E (2020) Using probiotics to flatten the curve of coronavirus disease COVID-2019 pandemic. Front Public Health 8. https://doi.org/10.3389/fpubh. 2020.00186

Belkacem N, Serafini N, Wheeler R, Derrien M, Boucinha L, Couesnon A, Cerf-Bensussan N, Boneca IG, Santo JPD, Taha MK, BourdetSicard R (2017) Lactobacillus paracasei feeding improves immune control of influenza infection in mice. PLoS One 12:e0184976. https://doi.org/10.1371/journal.pone.0184976

Belkaid Y, Hand T (2014) Role of the Microbiota in immunity and inflammation. Cell 157:121-141. https://doi.org/10.1016/j.cell.2014. 03.011

Berggren A, Lazou AI, Larsson N, Önning G (2011) Randomised, double-blind and placebo-controlled study using new probiotic lactobacilli for strengthening the body immune defence against viral infections. Eur J Nutr 50:203-210. https://doi.org/10.1007/s00394010-0127-6

Bingula R, Filaire M, Radosevic Robin N, Bey M, Berthon J-Y, Bernalier-Donadille A, Vasson M-P, Filaire E (2017) Desired turbulence? Gut-lung axis, immunity, and lung cancer. J Oncol 2017: 5035371-5035315. https://doi.org/10.1155/2017/5035371

Bisgaard H, Hermansen MN, Buchvald F, Loland L, Halkjaer LB, Bonnelykke K, Brasholt M, Heltberg A, Vissing NH, Thorsen SV, Stage M, Pipper CB (2007) Childhood asthma after bacterial colonization of the airway in neonates. N Engl J Med 357:1487-1495. https://doi.org/10.1056/NEJMoa052632

Blaut M, Marteau P, Miller GD, Antoine JM (2006) Probiotics and the intestinal microflora: what impact on the immune system, infections and ageing? Curr Nutr Food Sci 2:79-95. https://doi.org/10.2174/ 157340106775472029

Boyton RJ, Openshaw PJ (2002) Pulmonary defences to acute respiratory infection. Br Med Bull 61:1-12. https://doi.org/10.1093/bmb/61.1.1

Brown RL, Sequeira RP, Clarke TB (2017) The microbiota protects against respiratory infection via GM-CSF signaling. Nat Commun 8:1512. https://doi.org/10.1038/s41467-017-01803x

Budden KF, Gellatly SL, Wood DL, Cooper MA, Morrison M, Hugenholtz P, Hansbro PM (2017) Emerging pathogenic links between microbiota and the gut-lung axis. Nat Rev Microbiol 15:5563. https://doi.org/10.1038/nrmicro.2016.142

Bustamante-Marin XM, Ostrowski LE (2017) Cilia and mucociliary clearance. Cold Spring Harb Perspect Biol 9:a028241. https://doi. org/10.1101/cshperspect.a028241

Callahan LN, Phelan M, Mallinson M, Norcross MA (1991) Dextran sulfate blocks antibody binding to the principal neutralizing domain of human immunodeficiency virus type 1 without interfering with gp120-CD4 interactions. J Virol 65:1543-1550

Chang CS, Kao CY (2019) Current understanding of the gut microbiota shaping mechanisms. J Biomed Sci 26:59. https://doi.org/10.1186/ s12929-019-0554-5
Charlson ES, Chen J, Custers-Allen R, Bittinger K, Li H, Sinha R, Hwang J, Bushman FD, Collman RG (2010) Disordered microbial communities in the upper respiratory tract of cigarette smokers. PLoS One 5:e15216. https://doi.org/10.1371/journal.pone. 0015216

Chaudhuri N, Sabroe I (2008) Basic science of the innate immune system and the lung. Paediatr Respir Rev 9:236-242. https://doi.org/10. 1016/j.prrv.2008.03.002

Chen Y, Thai P, Zhao YH, Ho YS, De Souza MM, Wu R (2003) Stimulation of airway mucin gene expression by interleukin (IL)17 through IL-6 paracrine/autocrine loop. J Biol Chem 278:1703617043. https://doi.org/10.1074/jbc.M210429200

Chiba Y, Shida K, Nagata S, Wada M, Bian L, Wang C, Shimizu NT, Yamashiro Y, Kiyoshima-shibata J, Nanno M, Nomoto K (2010) Well-controlled proinfammatory cytokine responses of Peyer's patch cells to probiotic Lactobacillus casei. Immunology 130:352362. https://doi.org/10.1111/j.1365-2567.2009.03204.x

Corthesy B (2013) Multi-faceted functions of secretory $\operatorname{IgA}$ at mucosal surfaces. Front Immunol 4:185. https://doi.org/10.3389/fimmu. 2013.00185

Cuevas LE, Koyanagi A (2005) Zinc and infection: a review. Ann Trop Paediatr 25:149-160. https://doi.org/10.1179/146532805X58076

Cummings JE, Kovacic JP (2009) The ubiquitous role of zinc in health and disease. J Vet Emerg Crit Car (San Antonio) 19:215-240. https://doi.org/10.1111/j.1476-4431.2009.00418.x

Das S, Thakur BK (2015) Mucosal immune system of the respiratory tract: regulation of tolerance and immune response. The PulmoFace XV 2

Del Pinto R, Ferri C, Cominelli F (2017) Vitamin d axis in inflammatory bowel diseases: role, current uses and future perspectives. Int J Mol Sci 18:E2360. https://doi.org/10.3390/ijms18112360

Dhar D, Mohanty A (2020) Gut microbiota and Covid-19- possible link and applications. Virus Res 285:198018. https://doi.org/10.1016/j. virusres.2020.198018

Di Cerbo A, Palmieri B, Aponte M, Morales-Medina JC, Iannitti T (2016) Mechanisms and therapeutic effectiveness of lactobacilli. J Clin Pathol 69:187-203. https://doi.org/10.1136/jclinpath-2015-202976

Eccles MP, Grimshaw JM, Johnston M, Steen N, Pitts NB, Thomas R, Glidewell E, Maclennan G, Bonetti D, Walker A (2007) Applying psychological theories to evidence-based clinical practice: identifying factors predictive of managing upper respiratory tract infections without antibiotics. Implement Sci 2:26. https://doi.org/10.1186/ $1748-5908-2-26$

El Hage R, Hernandez-Sanabria E, Van de Wiele T (2017) Emerging trends in "smart probiotics": functional consideration for the development of novel health and industrial applications. Front Microbiol 8:1889. https://doi.org/10.3389/fmicb.2017.01889

Enaud R, Prevel R, Ciarlo E, Beaufils F, Wieers G, Guery B, Delhaes L (2020) The gut-lung axis in health and respiratory diseases: a place for inter-organ and inter-kingdom crosstalks. Front Cell Infect Microbiol 10. https://doi.org/10.3389/fcimb.2020.00009

Fanos V, Pintus MG, Pintus R, Marcialis MA (2020) Lung microbiota in the acute respiratory disease: from coronavirus to metabolomics. J Pediatric Neonatal Individ Med 9:e090139. https://doi.org/10.7363/ 090139

Farache J, Koren I, Milo I, Gurevich I, Kim KW, Zigmond E, Furtado GC, Lira SA, Shakhar G (2013) Luminal bacteria recruit CD1031 dendritic cells into the intestinal epithelium to sample bacterial antigens for presentation. Immunity 38:581-595. https://doi.org/10. 1016/j.immuni.2013.01.009

Feng Z, Wang Y, Qi W (2020) The small intestine, an underestimated site of SARS-CoV-2 infection: from Red Queen effect to probiotics. Preprints 2020:2020030161. https://doi.org/10.20944/ preprints202003.0161.v1

Fooks LJ, Gibson GR (2002) Probiotics as modulators of the gut flora. $\mathrm{Br}$ J Nutr 88:S39-S49. https://doi.org/10.1079/BJN2002628 
Frank DN, Feazel LM, Bessesen MT, Price CS, Janoff EN, Pace NR (2010) The human nasal microbiota and Staphylococcus aureus carriage. PLoS One 5:e10598. https://doi.org/10.1371/journal.pone.0010598

Fukada T, Kambe T (2014) Zinc signal in cellular functions and disorder. Springer, Tokyo

Gabryszewski SJ, Bachar O, Dyer KD, Percopo CM, Killoran KE, Domachowske JB, Rosenberg HF (2011) Lactobacillus-mediated priming of the respiratory mucosa protects against lethal Pneumovirus infection. J Immunol 186:1151-1161. https://doi.org/ 10.4049/jimmunol.1001751

Galdeano CM, Cazorla SI, Dumit JML, Vélez E, Perdigón G (2019) Beneficial effects of probiotic consumption on the immune system. Ann Nutr Metab 74:115-124. https://doi.org/10.1159/000496426

Galdeano CM, Núñez IN, de Moreno de LeBlanc A, Carmuega E, Weill R, Perdigon G (2011) Impact of a pro-biotic fermented milk in the gut ecosystem and in the systemic immunity using a non-severe protein-energy-malnutrition model in mice. BMC Gastroenterol 11:64. https://doi.org/10.1186/1471-230X-11-64

Gammoh NZ, Rink L (2017) Zinc in infection and inflammation. Nutrients 9:E624. https://doi.org/10.3390/nu9060624

Gielda LM, DiRita VJ (2012) Zinc competition among the intestinal microbiota. mBio 3:00171-00112. https://doi.org/10.1128/mBio. 00171-12

Gill HS, Rutherfurd KJ, Cross ML, Gopal PK (2001) Enhancement of immunity in the elderly by dietary supplementation with the probiotic Bifidobacterium lactis HN019. Am J Clin Nutr 74:833-839. https://doi.org/10.1093/ajcn/74.6.833

Gordon S (2008) Elie Metchnikoff: father of natural immunity. Eur J Immunol 38:3257-3264. https://doi.org/10.1002/eji.200838855

Grudzien M, Rapak A (2018) Effects of natural compounds on NK cell activation. J Immunol Res 2018:4868417-4868411. https://doi.org/ $10.1155 / 2018 / 4868417$

Gu S, Chen D, Zhang JN, Lv X, Wang K, Duan LP, Nie Y, Wu XL (2013) Bacterial community mapping of the mouse gastrointestinal tract. PLoS One 8:e74957. https://doi.org/10.1371/journal.pone.0074957

Guan W-J, Ni Z-Y, Hu Y, Liang W-H, Ou C-Q, He J-X, Liu L, Shan H, Lei C-L, Hui DSC, Du B, Li L-J, Zeng G, Yuen K-Y, Chen R-C, Tang C-L, Wang T, Chen P-Y, Xiang J, Li S-Y, Wang J-L, Liang ZJ, Peng Y-X, Wei L, Liu Y, Hu Y-H, Peng P, Wang J-M, Liu J-Y, Chen Z, Li G, Zheng Z-J, Qiu S-Q, Luo J, Ye C-J, Zhu S-Y, Zhong N-S, China Medical Treatment Expert Group for Covid-19 (2020) Clinical Characteristics of Coronavirus Disease 2019 in China. N Engl J Med 382(18):1708-1720. https://doi.org/10.1056/ NEJMoa2002032

Guillemard E, Tondu F, Lacoin F, Schrezenmeir J (2010) consumption of a fermented dairy product containing the probiotic Lactobacillus casei DN-114001 reduces the duration of respiratory infections in the elderly in a randomised controlled trial. Br J Nutr 103:58-68. https://doi.org/10.1017/S0007114509991395

Gunville CF, Mourani PM, Ginde AA (2013) The role of vitamin D in prevention and treatment of infection. Inflamm Allergy Drug Targets 12:239-245. https://doi.org/10.2174/ 18715281113129990046

Hamilton-Miller JM (2004) probiotics and prebiotics in the elderly. Postgrad Med 80:447-451. https://doi.org/10.1136/pgmj.2003.015339

Hao Q, Lu Z, Dong BR, Huang CQ, Wu T (2011) Probiotics for preventing acute upper respiratory tract infections. Cochrane Database Syst Rev 9:CD006895. https://doi.org/10.1002/ 14651858.CD006895.pub2

Harata G, He F, Hiruta N, Kawase M, Kunota A, Hiramatsu M, Yausi H (2010) Intranasal administration of Lactobacillus rhamnosus GG protects mice from $\mathrm{H} 1 \mathrm{~N} 1$ influenza virus infection by regulating respiratory immune responses. Lett Appl Microbiol 50:597-602. https://doi.org/10.1111/j.1472-765X.2010.02844.x

Harmsen HJ, de Goffau MC (2016) The human gut microbiota. Adv Exp Med Biol 902:95-108. https://doi.org/10.1007/978-3-319-31248-4_7
Heinonen S, Jartti T, Garcia C, Oliva S, Smitherman C, Anguiano E, de Steenhuijsen Piters WAA, Vuorinen T, Ruuskanen O, Dimo B, Suarez NM, Pascual V, Ramilo O, Mejias A (2016) Rhinovirus detection in symptomatic and asymptomatic children: value of host transcriptome analysis. Am J Respir Crit Care Med 193:772-782. https://doi.org/10.1164/rccm.201504-0749OC

Hill C, Guarner F, Reid G, Gibson GR, Merenstein DJ, Pot B, Morelli L, Canani RB, Flint HJ, Salminen S, Calder PC, Sanders ME (2014) Expert consensus document. The International Scientific Association for Probiotics and Prebiotics consensus statement on the scope and appropriate use of the term probiotic. Nat Rev Gastroenterol Hepatol 11:506-514. https://doi.org/10.1038/ nrgastro.2014.66

Ho AWS, Prabhu N, Betts RJ, Ge MQ, Dai X, Hutchinson PE, Lew FC, Wong KL, Hanson BJ, Macary PA, Kemeny DM (2011) Lung CD103+ dendritic cells efficiently transport influenza virus to the lymph node and load viral antigen onto MHC class I for presentation to CD8 T cells. J Immunol 187:6011-6021. https://doi.org/10.4049/ jimmunol.1100987

Hoffmann M, Kleine-Weber H, Schroeder S, Krüger N, Herrler T, Erichsen S, Schiergens TS, Herrler G, Wu N-H, Nitsche A, Müller MA, Drosten C, Pöhlmann S (2020) SARS-CoV-2 cell entry depends on ACE2 and TMPRSS2 and is blocked by a clinically proven protease inhibitor. Cell 181(2):271-280.e8. https://doi.org/10. 1016/j.cell.2020.02.052

Hojyo S, Fukada T $(2016,2016)$ Roles of zinc signaling in the immune system. J Immunol Res:1-21. https://doi.org/10.1155/2016/ 6762343

Hooper LV, Macpherson AJ (2010) Immune adaptations that maintain homeostasis with the intestinal microbiota. Nat Rev Immunol 10: 159-169. https://doi.org/10.1038/nri2710

Hua X, Vijay R, Channappanvar R, Athmer J, Meyerholz DK, Pagedar N, Tilly S, Perlman S (2018) Nasal priming by a murine coronavirus provides protective immunity against lethal heterologous virus pneumonia. JCI Insight 3:e99025. https://doi.org/10.1172/jci. insight.99025

Huang YJ, Erb-Downward JR, Dickson R, Curtis JL, Huffnagle GB, Han MK (2017) Understanding the role of the microbiome in COPD: principles, challenges and future directions. Transl Res 179:71-83. https://doi.org/10.1016/j.trsl.2016.06.007

Huang Y, Mao K, Chen X, Sun M-A, Kawabe T, Li W, Usher N, Zhu J, Urban JF Jr, Paul WE (2018) S1P-dependent interorgan trafficking of group 2 innate lymphoid cells supports host defense. Science 359: 114-119. https://doi.org/10.1126/science.aam5809

Huang C, Wang Y, Li X, Ren L, Zhao J, Hu Y, Zhang L, Fan G, Xu J, Gu X, Cheng Z, Yu T, Xias J, Wei Y, Wu W, Xie X, Yin W, Li H, Liu M, Xiao Y, Gao H, Guo L, Xie J, Wang G, Jiang R, Gao Z, Jin Q, Wang J, Cao B (2020) Clinical features of patients infected with 2019 novel coronavirus in Wuhan, China. Lancet 395:497-506. https://doi.org/10.1016/S0140-6736(20)30183-5

Huffnagle GB, Dickson RP, Lukacs NW (2017) the respiratory tract microbiome and lung inflammation: a two way street. Mucosal Immunol 10:299-306. https://doi.org/10.1038/mi.2016.108

Janssen WJ, Stefanski AL, Bochner BS, Evans CM (2016) Control of lung defence by mucins and macrophages: ancient defence mechanisms with modern functions. Eur Respir J 48:1201-1214. https:// doi.org/10.1183/13993003.00120-2015

Jayawardena R, Sooriyaarachchi P, Chourdakis M, Jeewandara C, Ranasinghe P (2020) Enhancing immunity in viral infections, with special emphasis on COVID-19: a review. Diabetes Metab Syndr 14:367-382. https://doi.org/10.1016/j.dsx.2020.04.015

Jeyaraman M, Gulati A, Anudeep TC, Shetty DU, Latha S, Ajay SS, Jain R, Santosh M (2020) Vitamin-D an immune shield against nCOVID-19. IJCRR 12:19-25. https://doi.org/10.31782/IJCRR. 2020.12095 
Kanauchi O, Andoh A, AbuBakar S, Yamamoto N (2018) Probiotics and paraprobiotics in viral infection: clinical application and effects on the innate and acquired immune systems. Curr Pharm Des 24:710 717. https://doi.org/10.2174/1381612824666180116163411

Kar M, Khan NA, Panwar A, Bais SS, Basak S, Goel R, Sopory S, Medigeshi GR (2019) Zinc chelation specifically inhibits early stages of dengue virus replication by activation of NF- $\mathrm{KB}$ and induction of antiviral response in epithelial cells. Front Immunol 10: 2347. https://doi.org/10.3389/fimmu.2019.02347

Kau AL, Ahern PP, Griffin NW, Goodman AL, Gordon JL (2011) Human nutrition, the gut microbiome and the immune system. Nature 474:327-336. https://doi.org/10.1038/nature10213

Kawahara T, Takahashi T, Oishi K, Tanaka H, Masuda M, Takahashi S, Takano M, Kawakami T, Fukushima K, Kanazawa H, Suzuki T (2015) Consecutive oral administration of Bifidobacterium longum MM-2 improves the defense system against influenza virus infection by enhancing natural killer cell activity in a murine model. Microbiol Immunol 59:1-12. https://doi.org/10.1111/1348-0421.12210

Kerry RG, Patra JK, Gouda S, Park Y, Shin H-S, Das G (2018) Benefaction of probiotics for human health: a review. J Food Drug Anal 26:927-939. https://doi.org/10.1016/j.jfda.2018.01.002

Khailova L, Baird CH, Rush AA, McNamee EN, Wischmeyer PE (2013) Lactobacillus rhamnosus GG improves outcome in experimental Pseudomonas aeruginosa pneumonia: Potential role of regulatory T cells. Shock 40:496-503. https://doi.org/10.1097/SHK. 0000000000000066

Kim SR, Kim HJ, Kim DI, Lee KB, Park HJ, Jeong JS, Cho SH, Lee YC (2015) Blockade of interplay between IL-17A and endoplasmic reticulum stress attenuates lps-induced lung injury. Theranostics 5: 1343-1362. https://doi.org/10.7150/thno.11685

King S, Glanville J, Sanders ME, Fitzgerald A, Varley D (2014) Effectiveness of probiotics on the duration of illness in healthy children and adults who develop common acute respiratory infectious conditions: a systematic review and meta-analysis. Br J Nutr 112: 41-54. https://doi.org/10.1017/S0007114514000075

Kokubo T, Komano Y, Tsuji R, Fujiwara D, Fujii T, Kanauchi O (2019) The effects of plasmacytoid dendritic cell-stimulative lactic acid bacteria, Lactococcus lactis strain plasma, on exercise-induced fatigue and recovery via immunomodulatory action. Int J Sport Nutr Exerc Metab:1-5. https://doi.org/10.1123/ijsnem.2018-0377

Kumpitsch C, Koskinen K, Schopf V, Moissl-Eichinger C (2019) The microbiome of the upper respiratory tract in health and disease. BMC Biol 17:87. https://doi.org/10.1186/s12915-019-0703-Z

Kumpu M, Kekkonen RA, Kautiainen H, Jarvenpaa S, Kristo A, Huovinen P, Pitkaranta A, Korpela R, Hatakka K (2012) Milk containing probiotic Lactobacillus rhamnosus GG and respiratory illness in children: a randomized, double-blind, placebo-controlled trial. Eur J Clin Nutr 66:1020-1023. https://doi.org/10.1038/ejcn.2012.62

Lakshmi B, Viswanath B, Sai Gopal DVR (2013) Probiotics as antiviral agents in shrimp aquaculture. J Pathogens 2013:1-13. https://doi. org/10.1155/2013/424123

Lemire JM, Adams JS, Kermani-Arab V, Bakke AC, Sakai R, Jordan SC (1985) 1,25-Dihydroxyvitamin D3 suppresses human T helper/ inducer lymphocyte activity in vitro. J Immunol 134:3032-3035

Lemon KP, Klepac-Ceraj V, Schiffer HK, Brodie EL, Lynch SV, Kolter R (2010) Comparative analyses of the bacterial microbiota of the human nostril and oropharynx. mBio 1:e00129-e00110. https://doi. org/10.1128/mBio.00129-10

Leonardi A, Zanoni S, De Lucia M, Amaretti A, Raimondi S, Rossi M (2013) Zinc uptake by lactic acid bacteria. ISRN Biotechnol 2013: 1-5. https://doi.org/10.5402/2013/312917

Li YC, Chen Y, Du J (2015) Critical roles of intestinal epithelial vitamin $\mathrm{D}$ receptor signaling in controlling gut mucosal inflammation. $\mathrm{J}$ Steroid Biochem Mol Biol 148:179-183. https://doi.org/10.1016/j. jsbmb.2015.01.011
Lin L, Lu L, Cao W, Li T (2020) Hypothesis for potential pathogenesis of SARS-CoV-2 infection-a review of immune changes in patients with viral pneumonia. Emerg Microbes Infect 9:727-732. https:// doi.org/10.1080/22221751.2020.1746199

Liu S, Hu P, Du X, Zhou T, Pei X (2013) Lactobacillus Rhamnosus GG Supplementation for Preventing Respiratory Infections in Children: a meta-analysis of randomized, placebo-controlled trials. Indian Pediatr 50:377-381. https://doi.org/10.1007/s13312-013-0123-Z

Liu S, Chan TC, Chu YT, Wu JT, Geng X, Zhao N, Cheng W, Chen E, King CC (2016) Comparative epidemiology of human infections with middle east respiratory syndrome and severe acute respiratory syndrome coronaviruses among healthcare personnel. PLoS One 11: e0149988. https://doi.org/10.1371/journal.pone.0149988

Llewellyn A, Foey A (2017) Probiotic modulation of innate cell pathogen sensing and signaling events. Nutrients 9:1156. https://doi.org/10. 3390/nu9101156

Looft T, Allen HK (2012) Collateral effects of antibiotics on mammalian gut microbiomes. Gut Microbes 3:463-467. https://doi.org/10.4161/ gmic. 21288

López-Moreno A, Aguilera M (2020) Probiotics dietary supplementation for modulating endocrine and fertility microbiota dysbiosis. Nutrients 12:757. https://doi.org/10.3390/nu12030757

Lule VK, Tomar SK, Chawla P, Pophaly S, Kapila S, Arora S (2020) Bioavailability assessment of zinc enriched lactobacillus biomass in a human colon carcinoma cell line (Caco-2). Food Chem 309: 125583. https://doi.org/10.1016/j.foodchem.2019.125583

Mäkivuokko H, Tiihonen K, Tynkkynen S, Paulin L, Rautonen N (2010) The effect of age and non-steroidal anti-inflammatory drugs on human intestinal microbiota composition. Br J Nutr 103:227-234. https://doi.org/10.1017/S0007114509991553

Marshall JS, Warrington R, Watson W, Kim HL (2018) An introduction to immunology and immunopathology. Allergy, Asthma Clin Immunol 14:49. https://doi.org/10.1186/s13223-018-0278-1

Marsland BJ, Trompette A, Gollwitzer ES (2015) The gut-lung axis in respiratory disease. Ann Am Thorac Soc 12:S150-S156. https://doi. org/10.1513/AnnalsATS.201503-133AW

Martinez-Moreno J, Hernandez JC, Urcuqui-Inchima S (2020) Effect of high doses of vitamin $\mathrm{D}$ supplementation on dengue virus replication, Toll-like receptor expression, and cytokine profiles on dendritic cells. Mol Cell Biochem 464:169-180. https://doi.org/10.1007/ s11010-019-03658-w

Maywald M, Wessels I, Rink L (2017) Zinc signals and immunity. Int J Mol Sci 18:e2222. https://doi.org/10.3390/ijms18102222

Mcdermott AJ, Huffnagle GB (2014) The microbiome and regulation of mucosal immunity. Immunology 142:24-31. https://doi.org/10. 1111/imm.12231

Mejias A, Dimo B, Suarez NM, Garcia C, Suarez-Arrabal MC, Jartti T, Blankenship D, Jordan-Villegas A, Ardura MI, Xu Z, Banchereau J, Chaussabel D, Ramilo O (2013) Whole blood gene expression profiles to assess pathogenesis and disease severity in infants with respiratory syncytial virus infection. PLoS Med 10:e1001549. https:// doi.org/10.1371/journal.pmed.1001549

Michael CA, David A (2013) The dynamic influence of commensal bacteria on the immune response to pathogens. Curr Opin Microbiol 16: 4-9. https://doi.org/10.1016/j.mib.2012.12.002

Mortaz E, Adcock LM, Folkerts G, Barnes PJ, Vos AP, Garssen J (2013) Probiotics in the management of lung diseases. Mediat Inflamm 2013:1-10. https://doi.org/10.1155/2013/751068

Mukherjee S, Hanidziar D (2018) More of the gut in the lung: how two microbiomes Meet in ARDS. Yale J Biol Med 91:143-149

Namasivayam S, Sher A, Glickman MS, Wipperman MF (2018) The microbiome and tuberculosis: early evidence for cross talk. mBio 9:e01420-e01418. https://doi.org/10.1128/mBio.01420-18

Neish AS (2014) Mucosal immunity and the microbiome. Ann Am Thorac Soc 11:S28-S32. https://doi.org/10.1513/AnnalsATS. 201306-161MG 
O’Dwyer DN, Dickson RP, Moore BB (2016) The lung microbiome, immunity and the pathogenesis of chronic lung disease. J Immunol 196:4839-4847. https://doi.org/10.4049/jimmunol.1600279

O'Toole PW, Claesson MJ (2010) Gut microbiota: changes throughout the lifespan from infancy to elderly. Int Dairy J 20:281-291. https:// doi.org/10.1016/j.idairyj.2009.11.010

Oliva S, Nardo DG, Ferrari F, Mallardo S, Rossi P, Patrizi G, Cucchiara S, Stronati L (2012) Randomised clinical trial: the effectiveness of Lactobacillus reuteri ATCC 55730 rectal enema in children with active distal ulcerative colitis. Aliment Pharmacol Ther 35:327334. https://doi.org/10.1111/j.1365-2036.2011.04939.x

Overbeck S, Rink L, Haase H (2008) Modulating the immune response by oral zinc supplementation: a single approach for multiple diseases. Arch Immunol Ther Exp (Warsz) 56:15-30. https://doi.org/ 10.1007/s00005-008-0003-8

Ozdemir O, Goksu Erol AY (2013) Preventative and therapeutic probiotic use in allergic skin condition: experimental and clinical findings. Biomed Res Int 2013:1-17. https://doi.org/10.1155/2013/932391

Parker A, Lawson MAE, Vaux L, Pin C (2018) Host-microbe interaction in the gastrointestinal tract. Environ Microbiol 20:2337-2353. https://doi.org/10.1111/1462-2920.13926

Patel PJ, Singh SK, Panaich S, Cardozo L (2013) The aging gut and the role of prebiotics, probiotics, and synbiotics: a review. J Clin Gerontol Geriatr 5:3-6. https://doi.org/10.1016/j.jcgg.2013.08.003

Pu F, Guo Y, Li M, Zhu H, Wang S, Shen X, He M, Huang C, He F (2017) Yogurt supplemented with probiotics can protect the healthy elderly from respiratory infections: a randomized controlled openlabel trial. Clin Interv Aging 12:1223-1231. https://doi.org/10.2147/ CIA.S141518

Qian Z, Travanty EA, Oko L, Edeen K, Berglund A, Wang J, Ito Y, Holmes KV, Mason RJ (2013) Innate immune response of human alveolar type II cells infected with severe acute respiratory syndrome-coronavirus. Am J Respir Cell Mol Biol 48:742-748. https://doi.org/10.1165/rcmb.2012-0339OC

Rautava S, Salminen S, Isolauri E (2009) Specific probiotics in reducing the risk of acute infections in infancy - a randomised, double-blind, placebo-controlled study. Br J Nutr 101:1722-1726. https://doi.org/ $10.1017 / \mathrm{S} 0007114508116282$

Razdan K, Singh K, Singh D (2020) Vitamin D levels and COVID-19 susceptibility: is there any correlation? Med Drug Discov 7:100051. https://doi.org/10.1016/j.medidd.2020.100051

Razzaque MS (2020) COVID-19 Pandemic: can maintaining optimal zinc balance enhance host resistance? Preprints 2020040006. https://doi.org/10.20944/preprints202004.0006.v1

Read SA, Obeid S, Ahlenstiel C, Ahlenstiel G (2019) The role of zinc in antiviral immunity. Adv Nutr 10:696-710. https://doi.org/10.1093/ advances/nmz013

Rerksuppaphol S, Rerksuppaphol L (2019) A randomized controlled trial of zinc supplementation in the treatment of acute respiratory tract infection in Thai children. Pediatr Rep 11:7954. https://doi.org/10. 4081/pr.2019.7954

Rinninella E, Raoul P, Cintoni M, Franceschi F, Donato Miggiano GA, Gasbarrini A, Mele MC (2019) What is the healthy gut microbiota composition? A Changing Ecosystem across Age, Environment, Diet, and Diseases. Microorganisms 7:14. https://doi.org/10.3390/ microorganisms 7010014

Rondanelli M, Giacosa A, Faliva MA, Perna S, Allieri F, Castellazzi AM (2015) Review on microbiota and effectiveness of probiotics use in older. World J Clin Cases 3:156-162. https://doi.org/10.12998/ wjcc.v3.i2.156

Rossi GA, Fanous H, Colin AA (2020) Viral strategies predisposing to respiratory bacterial superinfections. Pediatr Pulmonol 55:10611073. https://doi.org/10.1002/ppul.24699

Russell B, Moss C, George G, Santaolalla A, Cope A, Papa S, Hemelrijck MV (2020) Association between immune-suppressive and stimulating drugs and novel COVID-19 a systematic review of current evidence. Ecancer 14:1022. https://doi.org/10.3332/ecancer.2020.1022

Ryzhakov G, Chuk-Ke Lai C, Blazek K, To K-W, Hussell T, Udalova I (2011) IL-17 boosts proinflammatory outcome of antiviral response in human cells. J Immunol 187:5357-5362. https://doi.org/10.4049/ jimmunol.1100917

Salminen S, Nybom S, Meriluoto J, Collado MC, Vesterlund S, ElNezami H (2010) Interaction of probiotics and pathogens-benefits to human health? Curr Opin Biotechnol 21:157-167. https://doi.org/ 10.1016/j.copbio.2010.03.016

Science M, Johnstone J, Roth DE, Guyatt G, Loeb M (2012) Zinc for the treatment of the common cold: a systematic review and metaanalysis of randomized controlled trials. CMAJ 184:E551-E561. https://doi.org/10.1503/cmaj.111990

Seedorf H, Griffin NW, Ridaura VK, Reyes A, Cheng J, Rey FE, Smith MI, Simson GM, Scheffrahn RH, Woebken D, Spormann AM, Treuren WV, Ursell LK, Pirrung M, Robbins-Pianka A, Cantarel BL, Lombard V, Henrissat B, Knight R, Gordon JI (2014) Bacteria from diverse habitats colonize and compete in the mouse gut. Cell 159:253-266. https://doi.org/10.1016/j.cell.2014.09.008

Shankar AH, Prasad AS (1998) Zinc and immune function: the biological basis of altered resistance to infection. Am J Clin Nutr 68:447S463S. https://doi.org/10.1093/ajen/68.2.447S

Shi N, Li N, Duan X, Niu H (2017) Interaction between the gut microbiome and mucosal immune system. Mil Med Res 4:14. https://doi.org/10.1186/s40779-017-0122-9

Smith TJ, Rigassio-Radler D, Denmark R, Haley T, Touger-Decker R (2013) Effect of Lactobacillus rhamnosus LGG (R) and Bifidobacterium animalis ssp. lactis BB-12(R) on health-related quality of life in college students affected by upper respiratory infections. Br J Nutr 109:1999-2007. https://doi.org/10.1017/ S0007114512004138

Song JA, Kim HJ, Hong SK, Lee DH, Lee SW, Song CS, Kim KT, Choi IS, Lee JB, Park SY (2016) Oral intake of Lactobacillus rhamnosus M21 enhances the survival rate of mice lethally infected with influenza virus. J Microbiol Immunol Infect 49:16-23. https://doi.org/10. 1016/j.jmii.2014.07.011

Steinert RE, Lee YK, Sybesma W (2020) Vitamins for the gut microbiome. Trends Mol Med 26:137-140. https://doi.org/10. 1016/j.molmed.2019.11.005

Stokes KL, Currier MG, Sakamoto K, Lee S, Collins PL, Plemper RK, Moore ML (2013) The respiratory syncytial virus fusion protein and neutrophils mediate the airway mucin response to pathogenic respiratory syncytial virus infection. J Virol 87:10070-10082. https:// doi.org/10.1128/JVI.01347-13

Suara RO, Crowe JE (2004) Effect of Zinc Salts on respiratory syncytial virus replication. Antimicrob Agents Chemother 48:783-790. https://doi.org/10.1128/aac.48.3.783-790.2004

Sze MA, Dimitriu PA, Hayashi S, Elliott WM, McDonough JE, Gosselink JV, Cooper J, Sin DD, Mohn WW, Hogg JC (2012) The lung tissue microbiome in chronic obstructive pulmonary disease. Am J Respir Crit Care Med 185:1073-1080. https://doi.org/10. 1164/rccm.201111-2075OC

Tabbers MM, Boluyt N, Berger MY, Benninga MA (2011) Nonpharmacologic treatments for childhood constipation: systematic review. Pediatrics 128:753-761. https://doi.org/10.1542/peds. 2011-0179

Tapiovaara L, Pitkaranta A, Korpela R (2016) Probiotics and the upper respiratory tract - a review. Pediatric. Infect Dis 1:19. https://doi.org/ 10.21767/2573-0282.100019

Taylor SL, Wesselingh S, Rogers GB (2016) Host-microbiome interactions in acute and chronic respiratory infections. Cell Microbiol 18: 652-662. https://doi.org/10.1111/cmi.12589

te Velthuis AJW, van den Worm SHE, Sims AC, Baric RS, Snijder EJ, Van Hemert MJ (2010) Zn2+ inhibits coronavirus and arterivirus rna polymerase activity in vitro and zinc ionophores block the 
replication of these viruses in cell culture. PLoS Pathog 6:e1001176. https://doi.org/10.1371/journal.ppat.1001176

Thomas M, Bomar PA (2020) Upper respiratory tract infection. [Updated 2020 Feb 4]. In: StatPearls [Internet]. StatPearls Publishing, Treasure Island. Available from: https://www.ncbi.nlm.nih.gov/ books/NBK532961/

Thomas S, Izard J, Walsh E, Batich K, Chongsathidkeit P, Clarke G, Sela DA, Muller AJ, Mullin JM, Albert K, Gilligan JP, DiGuilio K, Dilbarova R, Alexander W, Prendergast GC (2017) The host microbiome regulates and maintains human health: a primer and perspective for non-microbiologists. Cancer Res 77:1783-1812. https://doi.org/10.1158/0008-5472.CAN-16-2929

Trompette A, Gollwitzer ES, Yadava K, Sichelstiel AK, Sprenger N, Ngom-Bru C, Blanchard C, Junt T, Nicod LP, Marsland BJ (2014) Gut microbiota metabolism of dietary fiber influences allergic airway disease and hematopoiesis. Nat Med 20:159-166. https://doi. org/10.1038/nm.3444

Topping DL, Clifton PM (2001) Short-chain fatty acids and human colonic function: roles of resistant starch and nonstarch polysaccharides. Physiol Rev 81:1031-1064. https://doi.org/10.1152/ physrev.2001.81.3.1031

Urashima M, Segawa T, Okazaki M, Kurihara M, Wada Y, Ida H (2010) Randomized trial of vitamin D supplementation to prevent seasonal influenza A in schoolchildren. Am J Clin Nutr 91:1255-1260. https://doi.org/10.3945/ajcn.2009.29094

Van Riel D, Munster VJ, de Wit E, Rimmelzwaan GF, Fouchier RAM, Osterhaus Ab DME, Kuiken T (2006) H5N1 virus attachment to lower respiratory tract. Science 312:399. https://doi.org/10.1126/ science. 1125548

Vieira AT, Rocha VM, Tavares L, Garcia CC, Teixeira MM, Oliveira SC, Cassali GD, Gamba C, Martins FS, Nicoli JR (2016) Control of Klebsiella pneumoniae pulmonary infection and immunomodulation by oral treatment with the commensal probiotic Bifidobacterium longum 5(1A). Microbes Infect 18:180-189. https://doi.org/10.1016/j.micinf.2015.10.008

Wang Y, Li X, Ge T, Xiao Y, Liao Y, Cui Y, Zhang Y, Ho W, Yu G, Zhang T (2016) Probiotics for prevention and treatment of respiratory tract infections in children A systematic review and metaanalysis of randomized controlled trials. Medicine 95:e4509. https://doi.org/10.1097/MD.0000000000004509
Wang X, Hu W, Zhu L, Yang Q (2017) Bacillus subtilis and surfactin inhibit the transmissible gastroenteritis virus entering intestinal epithelial cells. Biosci Rep 37:BSR20170082. https://doi.org/10.1042/ BSR20170082

Wilson MT, Hamilos DL (2014) The nasal and sinus microbiome in health and disease. Curr Allergy Asthma Rep 14:485. https://doi. org/10.1007/s11882-014-0485-X

Xu Y, Li X, Zhu B, Liang H, Fang C, Gong Y, Guo Q, Sun X, Zhao D, Shen J, Zhang H, Liu H, Xia H, Tang J, Zhang K, Gong S (2020) Characteristics of pediatric SARS-CoV-2 infection and potential evidence for persistent fecal viral shedding. Nat Med 26:502-505. https://doi.org/10.1038/s41591-020-0817-4

Yasui H, Kiyoshima J, Hori T, Shida K (1999) Protection against influenza virus infection of mice fed Bifidobacterium breve YIT4064. Clin Diagn Lab Immunol 6:186-192. https://doi.org/10.1128/CDLI. 6.2.186-192.1999

Zelaya H, Alvarez S, Kitazawa H, Villena J (2016) Respiratory antiviral immunity and immunobiotics: beneficial effects on inflammationcoagulation interaction during influenza virus infection. Front Immunol 7:633. https://doi.org/10.3389/fimmu.2016.00633

Zhang H, Yeh C, Jin Z, Ding L, Liu BY, Zhang L, Dannelly HK (2018) improvement of upper respiratory infection rate. Synth Syst Biotechnol 3:113-120. https://doi.org/10.1016/j.synbio.2018.03. 001

Zhao Y, Ran Z, Jiang Q, Hu N, Yu B, Zhu L, Shen L, Zhang S, Chen L, Chen H, Jiang J, Chen D (2019) Vitamin D alleviates rotavirus infection through a microrna-155-5p mediated regulation of the TBK1/IRF3 signaling pathway in vivo and in vitro. Int J Mol Sci 20:3562. https://doi.org/10.3390/ijms20143562

Zolnikova O, Komkova I, Potskherashvili N, Trukhmanov A, Ivashkin V (2018) Application of probiotics for acute respiratory tract infections. Ital J Med 12:32. https://doi.org/10.4081/itjm.2018.931

Yang Y, Song H, Wang L, Dong W, Yang Z, Yuan P, Wang K, Song Z (2017) Antiviral effects of a probiotic metabolic products against transmissible gastroenteritis coronavirus. J Prob Health 5:3. https:// doi.org/10.4172/2329-8901.1000184

Publisher's note Springer Nature remains neutral with regard to jurisdictional claims in published maps and institutional affiliations. 